\title{
Response of drought index to land use types in the Loess Plateau of Shaanxi, China
}

\author{
Weixuan Wang \\ Northwest A\&F University \\ Chenfeng Cui ( $\square$ cuichenfeng@163.com) \\ Northwest A\&F University \\ Weihua Yu \\ Northwest A\&F University \\ Liang Lu \\ Northwest A\&F University
}

\section{Research Article}

Keywords: land use, drought index, SPI

Posted Date: February 18th, 2022

DOI: https://doi.org/10.21203/rs.3.rs-1358949/v1

License: (c) (1) This work is licensed under a Creative Commons Attribution 4.0 International License. Read Full License 


\title{
Response of drought index to land use types in the Loess
}

\section{Plateau of Shaanxi, China}

\author{
Weixuan Wang ${ }^{1}$, Chenfeng Cui ${ }^{1,2, *}$, Weihua $\mathrm{Yu}^{1,2}$, Liang $\mathrm{Lu}^{1}$ \\ (1. College of Water Resources and Architectural Engineering, Northwest A\&F University, \\ Yangling, Shaanxi, 712100, China; \\ 2. The Key Laboratory of Agricultural Soil and Water Engineering in Arid Areas, Ministry \\ of China, Northwest A\&F University, Yangling, Shaanxi 712100, China; \\ * Correspondence: cuichenfeng@163.com)
}

Abstract: From 1980 to 2010, the types of land use in the Loess Plateau region of Shaanxi changed, which is affected the changes of drought. To study the impact of reform and opening up and the project of returning farmland to forests on drought in the study area, the drought index SPI of 8 stations was obtained on the basis of the meteorological and land use data of the study area from 1980 to 2010. From the perspective of various land-use types, based on univariate linear regression, the time envelope is divided into five periods, and the impacts of different land-use types on drought are analyzed one by one. From 1980 to 2010, the outcomes showed that the drought intensity of forest was the largest, the arable land is the second largest and town and country is final. However, arable land had the greatest response to drought index, followed by town and country, and forest had the weakest response to drought index. From 2000 to 2010, the drought intensity of the forest was the largest, followed by town and country and arable land. Also, drought index has the strongest response to the forest, the second is town and country, the arable land is final. The area of forest, grass and town and country is increasing, the proportion of arable land cuts down year by year, and the types of land use are constantly undergoing complex changes. The drought index has a strong response to the change of arable land to grass and arable land to town and country, but has a weak response to the mutual transformation of grass and town and country.

Keywords: land use; drought index; SPI

\section{Introduction}

Drought is a kind of natural disaster which is common and widespread, with high frequency, long time span, wide impact and profound influence on agriculture and economy. In China, drought losses account for more than $15 \%$ of natural disasters. The area of drought is as high as $57 \%$ of the total area affected by natural disasters. The frequency of droughts accounts for about $1 / 3$ of the total frequency of disasters [1]. Drought affects four major geographical aspects: meteorology, hydrology, agriculture, and social economy. The classification methods have reached a consensus [2]. Since long-term meteorological drought will form soil and hydrological drought, and long-term soil and hydrological drought will lead to agricultural drought, meteorological drought indicators are particularly important for drought monitoring

Weixuan Wang (2001-), female, undergraduate. Hydrology and water resources. 
[3]. Therefore, the study of meteorological drought has extremely important practical significance.

China began to carry out the major measures of reform and opening up in the late 1970s. The level of industrialization has been raised by big percentages, urbanization has sped up, and the categories of land use have changed significantly. At the same time, it also has a certain impact on climate change, with intensified climate warming and frequent occurrence of extreme climates. Since the late 1990s, due to the intensified global warming and the continued weakening of the East Asian summer monsoon, droughts across China have become more frequent and severe. Especially in some parts of the north, interdecadal droughts occurred in 1995, 1997 and 2000 in the eastern part of Northwest China and North China [4,5]. The Loess Plateau is situated in the eastern part of Northwest China, with severe soil erosion and frequent droughts, which have a huge impact on the local social economy and water resources management [6]. To change this situation, in the late 1990s, the project of returning farmland to the forest was first carried out in Shaanxi, Sichuan and Gansu provinces. Since then, the types of land use in Shaanxi have undergone great changes. From 1999 to 2008, China has finished 403 million mu (a Chinese unit of area, it is equal to $1 / 15$ of a hectare or $1 / 6$ an acre) of farmland to forest totally, of which 139 million mu of arable lands were turned into forests, 237 million mu of unused areas were turned into forests, and 27 million mu of mountains were closed for being turned into forests [7].

The evolution process of drought is controlled by many factors. Climate change, human activities and surface water system characteristics are the three main contributing elements of drought. These three factors jointly affect the time and space distribution pattern of drought, and then affect the evolution of drought $[8,9,10,11]$. The characteristics of the water system reflect the underlying surface factors that affect the evolution of drought, and the hysteresis and attenuation characteristics that affect the spread of drought [12]. Climate change directly affects the temporal and spatial pattern of drought by changing the time and space distribution of meteorological elements such as precipitation and temperature [13]. Human activities (land use behavior, reservoir construction, etc.) will change the characteristics and process of drought evolution, and land-use changes also influence drought [14]. Humans have a significant impact on drought by changing land-use patterns and changing the underlying factors that act on the spatial pattern of drought [15].

At present, research on Northwest China focuses on the effects of meteorological factors such as precipitation and temperature on drought. Kong et al. used the precipitation and soil moisture data to calculate SPI (standardized precipitation index) and SSMI (standardized soil moisture index), and used the run-length theory to identify drought characteristic variables, and studied the drought changes in Yulin City [16]. Wang et al. calculated SPI and SPEI of different scales to analyze characteristics of drought variation with time and space on the Loess Plateau in the past 57 years, and used cross wavelet transform to discuss the correlation analysis between drought index and atmospheric circulation [17]. Liu et al. established aridity index AI and concluded that precipitation and actual water vapor pressure are the main climatic factors affecting AI changes in Gansu, Ningxia, Qinghai, and Shaanxi, and the main climatic factors affecting AI changes in Xinjiang are potential evapotranspiration, solar Radiation and mean air 
temperature [18]. Droughts are not just caused by climate change. Different from the above research views, this paper studies its impact on drought from the perspective of land-use types.

Standardized precipitation index (SPI) has been extensively used as a drought monitoring index [19]. The SPI can better show the intensity and lasting time of drought, and is more susceptible to changes in drought. At the same time, the feature of applying on multiple time scales can provide service for drought monitoring at different time scales [20]. Sun et al. used SPI to do research on the drought characteristics of the Loess Plateau in Shaanxi, and concluded that the applicability of SPI is good in Shaanxi [21]. In order to study the influence of changes in land use categories caused by human activities such as reform and opening up and converting farmland to forests on the drought during this time span, SPI of 8 sites which is on the basis of the meteorological and land use data of the study area from 1980 to 2010 are obtained in this study. The Loess Plateau of Shaanxi is chosen as the research area. Meteorological observation data is used to calculate the drought index SPI in the study area from 1980 to 2010, and the response of the SPI to different land-use types is analyzed. According to the obtained remote sensing data, this performance is clearly depicted according to the periods of 1980-1990, 1990$1995,1995-2000,2000-2005,2005-2010$, to visualize changes in drought in more details in 6 periods.

\section{Materials and Methods}

\subsection{Study area}

Shaanxi Loess Plateau is situated at 3341'35" north latitude and 106 $19^{\circ} 14^{\prime \prime}$ east longitude, including Yulin, Yan'an, Tongchuan, Xianyang, Xi'an, Weinan, Yangling and parts of Baoji City. Its area of about 130,000 square kilometers. Northern Shaanxi is situated in the center of the Loess Plateau. The height is $900 \sim 1600 \mathrm{~m}$ above sea level. The height of the terrain decreases from northwest to southeast. It has the semi-arid temperate continental monsoon climate zone. It is dry and rainy, extremely lack of water resources, and the temporal distribution of temperature and precipitation is different greatly. The annual average precipitation is about $300 \mathrm{~mm}$, and the uneven spatial distribution is opposite to terrain. The Guanzhong part belongs to the southern part of the Loess Plateau and is located in the Weihe Plain, with an altitude of $325 \sim 900 \mathrm{~m}$. The annual average temperature is above $12^{\circ} \mathrm{C}$, and the annual average precipitation is $600-700 \mathrm{~mm}$. 


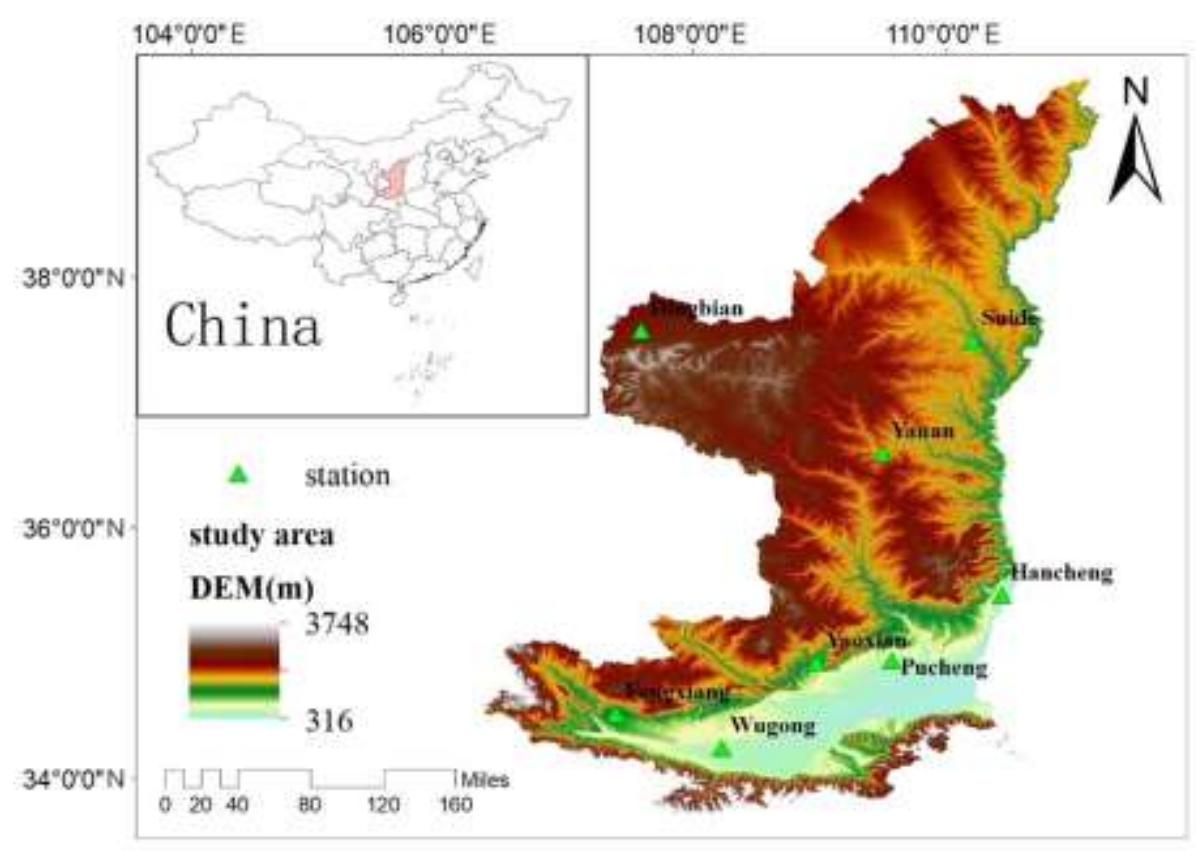

Figure 1 Location of the study area

\subsection{Data}

In this study, the data used include Digital Elevation Model (DEM) data, land use data and meteorological data.

The DEM data are from the Resource and Environmental Science and Data Center of the Chinese Academy of Sciences (https: // www.resdc.cn/). The spatial distribution data of China's altitude (DEM) in this website comes from the radar topography mapping SRTM (Shuttle Radar Topography Mission, SRTM) data of the US space shuttle Endeavour. SRTM data has the advantages of strong realism and free access. Many applied studies around the world use SRTM data to carry out the environmental analysis. The data set is $90 \mathrm{~m}$ provincial data generated by sorting and splicing based on the latest SRTM V4.1 data.

The land use data comes from the Resource and Environmental Science and Data Center of the Chinese Academy of Sciences (https://www.resdc.cn/). The years 1980, 1990, 1995, 2000,2005 and 2010 with a resolution of $1 \mathrm{~km}$ of land use data are used in this paper. After reclassification, there are 6 categories of land use of forest, arable land, unused area, grass, water area, and town and country. The categories of land use each year are shown in Figure 1.

The basic meteorological data is from the China Meteorological Data Network (http://data.cma.cn/). The daily data of the average temperature and precipitation of 8 meteorological stations in the Loess Plateau region of Shaanxi from 1980 to 2010 were obtained. These data are carefully filtered to get rid of unusual data, and next the cubic spline interpolation method is used to interpolate the individual missing measurement values. The geographic locations of meteorological stations and the types of land use in each year are shown in Table 1.

Table 1 information of stations 


\begin{tabular}{|c|c|c|c|c|c|c|c|c|c|c|}
\hline $\begin{array}{l}\text { station } \\
\text { num- } \\
\text { ber }\end{array}$ & name & $\begin{array}{l}\text { lati- } \\
\text { tude }\end{array}$ & $\begin{array}{l}\text { longi- } \\
\text { tude }\end{array}$ & height & 1980 & 1990 & 1995 & 2000 & 2005 & 2010 \\
\hline 53725 & Dingbian & 37.58 & 107.58 & 1361.3 & $\begin{array}{l}\text { arable } \\
\text { land }\end{array}$ & $\begin{array}{l}\text { arable } \\
\text { land }\end{array}$ & $\begin{array}{l}\text { ara- } \\
\text { ble } \\
\text { land }\end{array}$ & $\begin{array}{l}\text { arable } \\
\text { land }\end{array}$ & $\begin{array}{l}\text { town } \\
\text { and } \\
\text { coun- } \\
\text { try- } \\
\text { side }\end{array}$ & $\begin{array}{l}\text { town } \\
\text { and } \\
\text { coun- } \\
\text { try- } \\
\text { side }\end{array}$ \\
\hline 53754 & Suide & 37.5 & 110.22 & 928.5 & forest & forest & forest & forest & forest & forest \\
\hline 53845 & Yanan & 36.6 & 109.5 & 958.8 & forest & forest & forest & forest & forest & forest \\
\hline 53948 & Pucheng & 34.95 & 109.58 & 499.9 & $\begin{array}{l}\text { arable } \\
\text { land }\end{array}$ & $\begin{array}{l}\text { arable } \\
\text { land }\end{array}$ & grass & $\begin{array}{l}\text { town } \\
\text { and } \\
\text { coun- } \\
\text { try- } \\
\text { side }\end{array}$ & $\begin{array}{l}\text { town } \\
\text { and } \\
\text { coun- } \\
\text { try- } \\
\text { side }\end{array}$ & $\begin{array}{l}\text { town } \\
\text { and } \\
\text { coun- } \\
\text { try- } \\
\text { side }\end{array}$ \\
\hline 53955 & Hancheng & 35.47 & 110.45 & 458.8 & $\begin{array}{l}\text { arable } \\
\text { land }\end{array}$ & $\begin{array}{l}\text { arable } \\
\text { land }\end{array}$ & $\begin{array}{l}\text { ara- } \\
\text { ble } \\
\text { land }\end{array}$ & $\begin{array}{l}\text { arable } \\
\text { land }\end{array}$ & $\begin{array}{l}\text { arable } \\
\text { land }\end{array}$ & $\begin{array}{l}\text { town } \\
\text { and } \\
\text { coun- } \\
\text { try- } \\
\text { side }\end{array}$ \\
\hline 57025 & Fengxiang & 34.52 & 107.38 & 781.1 & $\begin{array}{l}\text { town } \\
\text { and } \\
\text { coun- } \\
\text { try- } \\
\text { side }\end{array}$ & $\begin{array}{l}\text { town } \\
\text { and } \\
\text { coun- } \\
\text { try- } \\
\text { side }\end{array}$ & grass & $\begin{array}{l}\text { town } \\
\text { and } \\
\text { coun- } \\
\text { try- } \\
\text { side }\end{array}$ & $\begin{array}{l}\text { town } \\
\text { and } \\
\text { coun- } \\
\text { try- } \\
\text { side }\end{array}$ & $\begin{array}{l}\text { town } \\
\text { and } \\
\text { coun- } \\
\text { try- } \\
\text { side }\end{array}$ \\
\hline
\end{tabular}

(a) $\mathrm{N}$

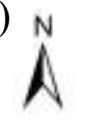

A ataise

2 forest

Dresi

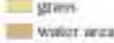

E trmuand ctratrn

- Insonal lan! (b)

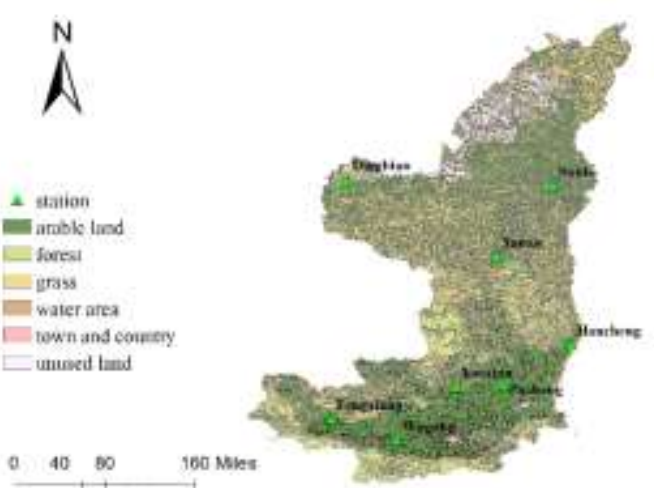


(c)
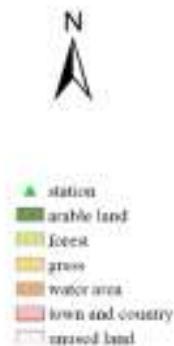

$0.40 \quad$ no

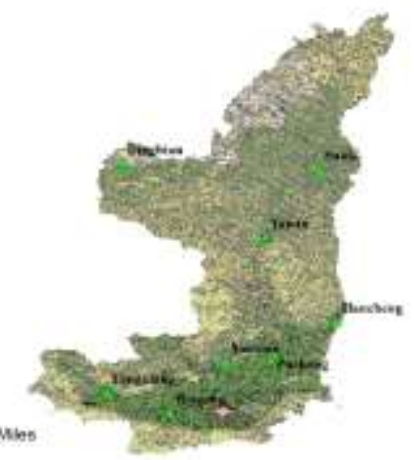

(e)
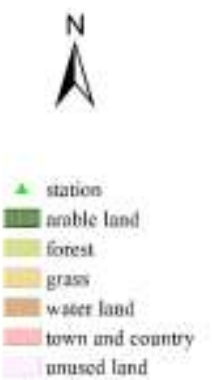

$0 \quad 40 \quad 60$ (d)
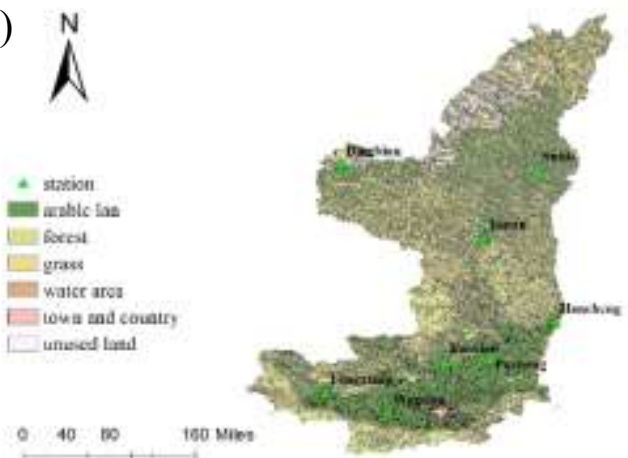

(f)

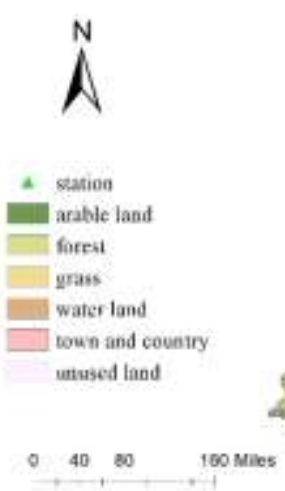

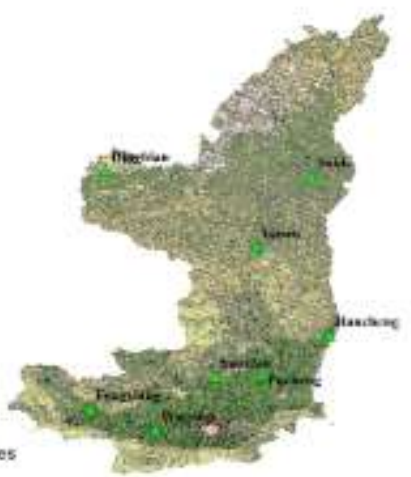

Figure 2 Land use of study area in 1980(a),1990(b),1995(c),2000(d),2005(e),2010(f)

\subsection{Methodology}

\subsubsection{Standardized Precipitation Index}

The Standardized Precipitation Index (SPI) was put forward by McKee et al. in 1993 [19]. It is a common analytical method in precipitation analysis and drought monitoring, and has been extensive applied in meteorological drought monitoring [22,23]. The following are the specific calculation steps.

The probability density function of the $\Gamma$-distribution of the monthly precipitation x:

$$
\begin{gathered}
z_{i}=\frac{6}{c_{s}}\left(\frac{c_{s}}{2} \varphi_{i}+1\right)^{\frac{1}{3}}-\frac{6}{c_{s}}+\frac{c_{s}}{6} \\
\Gamma(\gamma)=\int_{0}^{\infty} x^{\gamma-1} e^{-x} d x
\end{gathered}
$$

$\beta>0, \Upsilon>0$ are scale and form parameters, respectively, $\beta$ and $\Upsilon$ can be obtained by the maximum likelihood estimation method:

$$
\begin{gathered}
\hat{\gamma}=\frac{1+\sqrt{1+4 A / 3}}{4 A} \\
\hat{\beta}=\bar{x} / \hat{\gamma}
\end{gathered}
$$




$$
A=\lg \bar{x}-\frac{1}{n} \sum_{i=1}^{n} \lg x_{i}
$$

For the precipitation $x_{0}$ in a certain year, the probability that the random variable $x$ is less than the event $x_{0}$ can be calculated as:

$$
P\left(x<x_{0}\right)=\int_{0}^{\infty} f(x) d x
$$

Using numerical integration, an estimate of event probability can be calculated by substituting (1) into (6).

The above formula does not take the case into account where the precipitation is 0 . In reality, the situation where the precipitation is 0 still exists. The probability of an event with zero precipitation is estimated by:

$$
P(x=0)=m / n
$$

$\mathrm{m}$ is the number of samples with 0 precipitation, and $\mathrm{n}$ is the total number of samples.

Normalize the probability of $\Gamma$ distribution and solve for the SPI value:

$$
S P I=S \frac{t-\left(c_{2} t+c_{1}\right) t+c_{0}}{\left(\left(d_{3} t+d_{2}\right) t+d_{1}\right) t+1}
$$

$t=\sqrt{\ln \frac{1}{P^{2}}}$, when $P>0.5, P=1.0-P, \quad \mathrm{~S}=1 ;$ when $P \leqslant 0.5, \quad S=-1$ 。 $c_{0}=2.515517, \quad c_{1}=0.802853, \quad c_{2}=0.012328, \quad d_{1}=1.432788, \quad d_{2}=0.189269$, $d_{3}=0.001308$ 。

\subsubsection{Univariate Linear Regression}

Linear regression is mainly used to describe the linear relationship between the dependent variable $\mathrm{y}$ and the independent variable $\mathrm{x}$. The univariate linear regression method is to analyze the relationship between several data point sets $\left(x_{i}, y_{i}\right)(i=1,2, \ldots, n)$, and draw up a linear regression equation between variables $\mathrm{x}$ and $\mathrm{y}$. Its basic formula is:

$$
y_{i}=A x_{i}+B(i=1,2, \cdots, n)
$$

\subsubsection{Land Use Type Transfer Matrix}

The land use transfer matrix can reflect the change of the land use structure in all aspects and show how the land use changes [24]. It originates from the quantitative description of system state and state transition in system analysis, and represents the procedure of system transition from time $\mathrm{S}$ to time $\mathrm{S}+1$ in a certain period. It can effectively reflect the temporal and spatial evolution of land use patterns [25], and its formula is:

$$
s_{i j}=\left[\begin{array}{cccc}
S_{11} & S_{12} & \cdots & S_{1 n} \\
S_{21} & S_{22} & \cdots & S_{2 n} \\
\cdots & \cdots & \cdots & \cdots \\
S_{n 1} & S_{n 2} & \cdots & S_{n n}
\end{array}\right]
$$

In the formula: $\mathrm{S}_{\mathrm{ij}}$ is the land-use status at the beginning and end of the period; $\mathrm{n}$ is the number of land-use types.

At present, the vector in the commonly used land-use state transition matrix can be the area of land use type, or the probability of transition from original land-use type to the final land-use type, which is called the Markov transition probability matrix [26]. The land-use type area is used in this paper to carry out the transfer analysis of the land use type. 


\section{Results and Analysis}

\subsection{From 1980 to 1990}

From the land-use type transfer matrix (Table 2), the types of land use in the study area underwent a complex mutual transformation, and the area of arable land, water area, and unused land decreased by $0.02 \%, 3.54 \%$, and $1.89 \%$, respectively. Areas of forest, grass and town and country increased by $0.13 \%, 0.17 \%$ and $3.56 \%$ respectively. The water area decreased the most, mainly transferred to arable land, while the town and country increased the most at this time, and the main source of transfer was arable land. This is due to the fact that China's economy began to develop at this time and urbanization began to accelerate.

Table 2 Transfer matrix of land use types in the study area from 1980 to $1990(\mathrm{~km} 2)$

\begin{tabular}{|c|c|c|c|c|c|c|}
\hline \multirow[b]{2}{*}{1980} & \multicolumn{6}{|c|}{1990} \\
\hline & Grass & $\begin{array}{l}\text { Town and } \\
\text { country }\end{array}$ & Arable land & Forest & Water area & Unused area \\
\hline Grass & $\begin{array}{c}42201.2205 \\
1\end{array}$ & 2.557753 & 2708.469982 & 411.397571 & 35.814914 & 262.164944 \\
\hline $\begin{array}{l}\text { Town and } \\
\text { country }\end{array}$ & 3.513511 & $\begin{array}{c}1778.6743 \\
57\end{array}$ & 516.939021 & 1.105836 & & 0.376887 \\
\hline Arable land & $\begin{array}{c}2360.70057 \\
1\end{array}$ & $\begin{array}{c}153.46832 \\
2\end{array}$ & 50263.53377 & 189.814082 & 50.716512 & 95.135768 \\
\hline Forest & 441.991315 & 4.801844 & 282.502519 & 19671.1085 & 2.092333 & 11.382358 \\
\hline Water area & 74.129365 & 0.061531 & $\begin{array}{c}142.95944 \\
3\end{array}$ & 8.376883 & $\begin{array}{c}1363.9879 \\
46\end{array}$ & 7.21326 \\
\hline Unused area & 186.94696 & 4.715451 & 110.9011 & 15.545843 & 9.464633 & 5749.66462 \\
\hline
\end{tabular}

During 1980-1990, the land use types of the eight study sites did not change, the SPI values increased, and the intensity of drought decreased (Fig. 2). Taking the average value of the SPI of the sites of each utilization type, the SPI value of the forest in 1980 was -0.42773 , the SPI value of the arable land was -0.48812 , and the SPI value of the town and country was -0.47317 . In 1990, the SPI of the forest is -0.30283 , the SPI value of arable land is -0.31011 , and the SPI value of town and country is -0.35354 . By observing the change of SPI of each land-use type, the SPI of arable land has the largest change with a rate of change of $0.00902 \mathrm{yr}-$ 1 , while the forest type has the smallest change with a rate of change of $0.005051 \mathrm{yr}-1$. In this stage, arable land has the greatest impact on drought because crops are affected by climatic conditions. Although the forest has the least impact on drought, overall, the drought intensity of forest land is relatively high. 


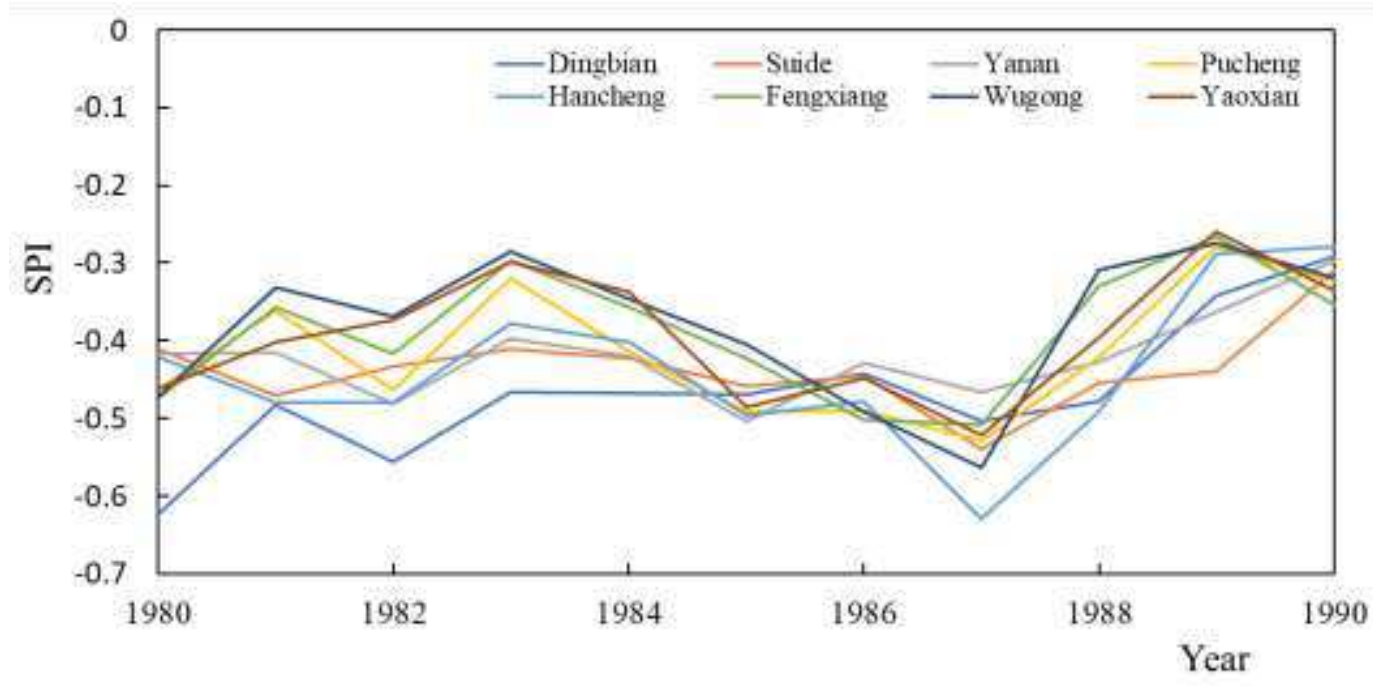

Figure 2 SPI changes at each site from 1980 to 1990

\subsection{From 1990 to 1995}

From 1990 to 1995, according to the land use type transition matrix (Table 3), only the unused land type decreased by $19.87 \%$, mainly to grass, followed by arable land. The areas of arable land, forest, grass, water area and town and country all increased by $0.27 \%, 0.60 \%$, $1.64 \%, 0.39 \%$ and $6.29 \%$ respectively. The largest increase is in town and country, and the main source of transfer of it is arable land. Similar to the situation in the 1980s, China's urbanization has developed rapidly, and unused land has also been developed, providing a guarantee for China's industrialization development.

Table 3 Transfer matrix of land use types in the study area from 1990 to $1995(\mathrm{~km} 2)$ 1995

1990

\begin{tabular}{ccccc}
\hline Grass & $\begin{array}{c}\text { Town and } \\
\text { country }\end{array}$ Arable land Forest $\quad$ Water area Unused area
\end{tabular}

Grass

44185.7751

6.635969

656.486777

$231.971975 \quad 53.569883$

133.6654

$$
6
$$

Town and

16.711513

1811.5095

111.51209

2.780686

1.796169

country

78

Arable land

384.005471

256.80545

53126.6207

134.428586

68.879502

49.567196

Forest

$233.240712 \quad 10.88188$

85.898481

19967.2646

5.636921

13.107064

$$
2
$$

Water area

$$
39.578843
$$

0.589351

86.454135

3.107755

1321.7396

3.619636

18

Unused area

1247.21807

2

140.81845

64.488865

13.785722

4653.807856

During 1990-1995, the SPI values all showed a downward trend, and the drought intensity increased (Fig. 3). In 1990, the SPI value of forest was the largest, which was -0.30283 , and the SPI value of town and country was the smallest, which was -0.35354 . In 1995, the SPI value of grass was the largest, which was -0.53743 , and the SPI value of forest was the smallest, 
which was -0.58723 . In Pucheng and Fengxiang, changes in land use types occurred during this period. Pucheng changed from arable land to grass, and Fengxiang changed from town and country to grass. The change rate of SPI in Pucheng was $-0.0367 \mathrm{yr}^{-1}$, and the change rate of SPI in Fengxiang was $-0.0187 \mathrm{yr}^{-1}$, indicating that the change from town and country to grass had less impact on SPI. The change of the underlying surface from town and country to grass led to the increase of vegetation, and the urban heat island effect was alleviated, which had an impact on SPI. Compared with other sites with unchanged land use types, the changes in SPI values are all larger than those with changes in land use. Among them, the forest land type site has the smallest SPI value change rate, which is $-0.0402 \mathrm{yr}^{-1}$. Similar to the previous stage, the response of the drought index to the arable land is greater than that of the forest, but the drought intensity of the forest land is still the largest, followed by the arable land, and finally the town and country. At this time, the disturbance of arable land by human activities is less than that of town and country.

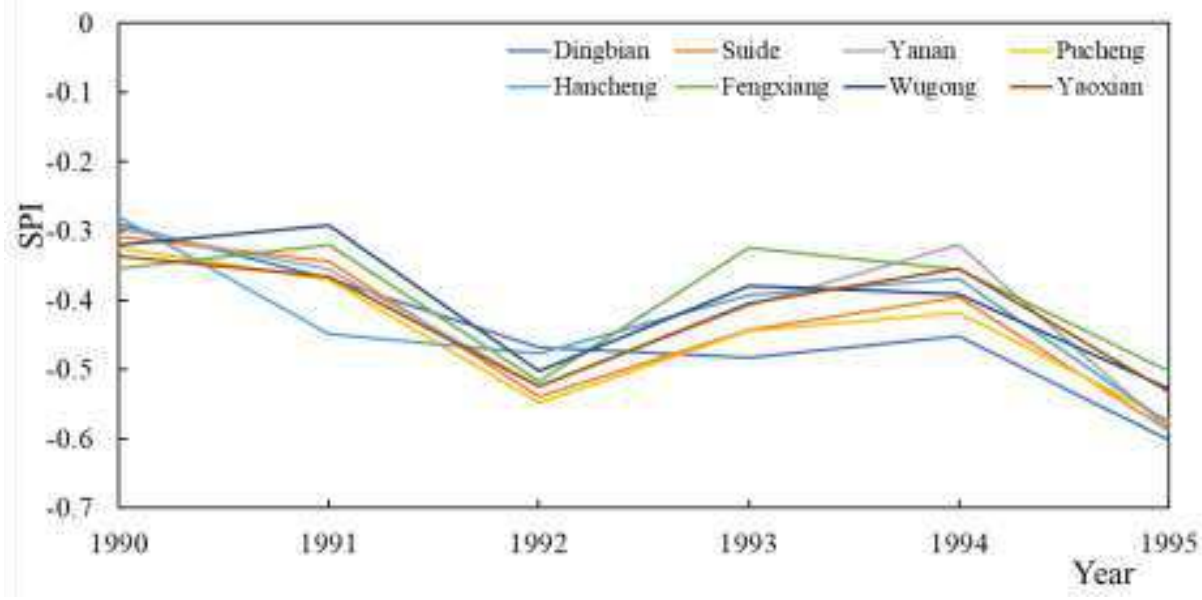

Figure 3 SPI changes at each site from 1990 to 1995

\subsection{From 1995 to 2000}

From 1995 to 2000, according to the land use type transition matrix (Table 4), arable land, grass and water area all decreased by $0.05 \%, 0.37 \%$ and $3.53 \%$ respectively. Forest land, town and country and unused land increased by $0.41 \%, 6.16 \%$ and $0.13 \%$ respectively. The water area with the most reduction are mainly arable land and grassland. Affected by the rapid development of economic construction and urbanization, the area of town and country has increased rapidly, and the main types of transfer are arable land and grassland.

Table 4 Transfer matrix of land use types in the study area from 1995 to $2000(\mathrm{~km} 2)$

\begin{tabular}{|c|c|c|c|c|c|c|}
\hline \multirow[b]{2}{*}{1995} & \multicolumn{6}{|c|}{2000} \\
\hline & Grass & $\begin{array}{l}\text { Town and } \\
\text { country }\end{array}$ & Arable land & Forest & Water area & Unused area \\
\hline Grass & $\begin{array}{c}45689.2574 \\
1\end{array}$ & 22.925261 & 246.151783 & 78.586824 & 20.021979 & 59.611618 \\
\hline $\begin{array}{l}\text { Town and } \\
\text { country }\end{array}$ & 0.185498 & $\begin{array}{c}2067.6753 \\
98\end{array}$ & 19.934811 & 0.549288 & 0.077234 & \\
\hline Arable land & 154.05456 & 130.27415 & 53800.00563 & 41.393344 & 34.722952 & 42.206942 \\
\hline
\end{tabular}




$\begin{array}{ccccccc}\text { Forest } & 18.433184 & 4.009388 & 54.016233 & 20351.8924 & 2.030777 & 0.707807 \\ & & & & 2 & & \\ \text { Water area } & 36.094969 & 1.765388 & 58.585737 & 2.027309 & 1360.9160 & 1.25 \\ & & & & & 83 & \\ \text { Unused area } & 52.760802 & & 16.482095 & 20.660092 & 0.640381 & 4761.904691\end{array}$

During the period, according to Figure 4, the SPI showed a roughly increasing trend. In 1997, a severe drought occurred, and the SPI decreased. In 1995, the SPI value of grass was the largest, which was -0.53743 , and the SPI value of forest was the smallest, which was 0.58723 . In 2000, the SPI value of forest was still the smallest, which was -0.50254 . The SPI value of town and country is the largest at -0.41615 . Comparing the change speed of each landuse type, the forest has the smallest change rate, which is $0.0043 \mathrm{yr}-1$. The change rate of arable land is the largest, which is $0.01234 \mathrm{yr}-1$. During this period, both Pucheng and Fengxiang were urbanized, and the grass areas were converted into town and country areas. The average change rate of the two sites was $0.01028 \mathrm{yr}-1$, which was relatively small. The large-area greening and the low degree of grassland development in the city alleviated to a certain extent the influence of land use type change on drought. This stage is still the same as the previous stage, the drought intensity of forest is the largest, but the impact on drought is the least. Arable land has a greater impact on drought, but the intensity of drought is bigger than that of forest and greater than that of town and country.

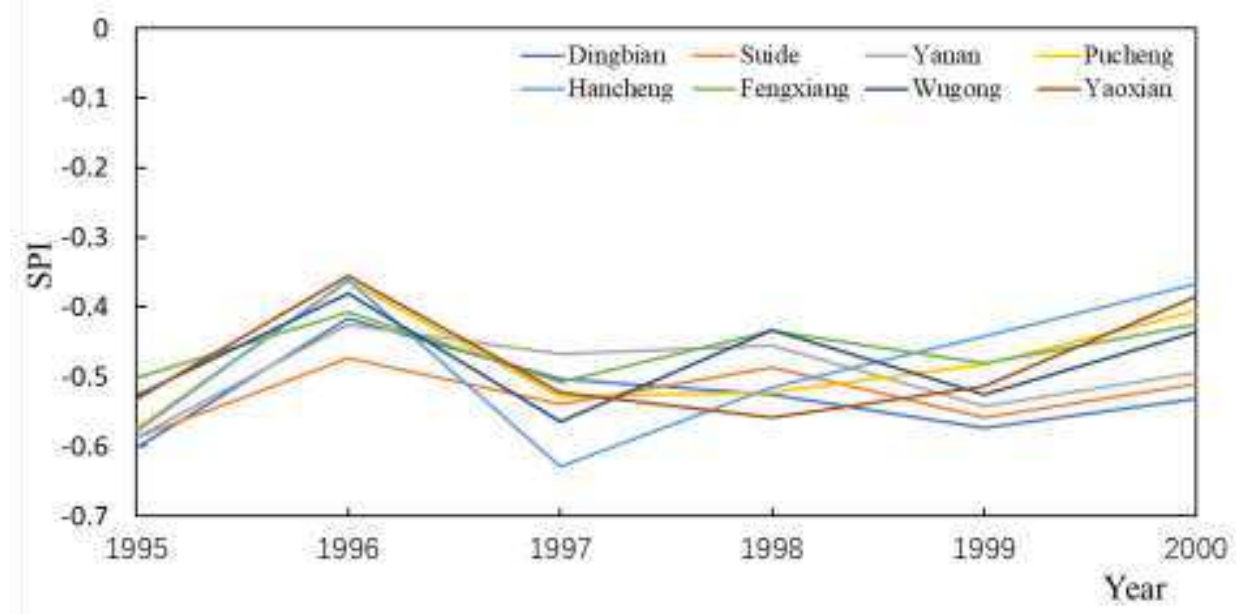

\subsection{From 2000 to 2005}

Figure 4 SPI changes at each site from 1995 to 2000

From 2000 to 2005, according to Table 5, arable land and unused land decreased by $2.58 \%$ and $0.75 \%$ respectively. Areas of forest, grass, water area and town and country all increased by $4.94 \%, 0.09 \%, 4.46 \%$ and $10.30 \%$ respectively. In the late $1990 \mathrm{~s}$, the project of returning farmland to the forest was implemented in Shaanxi, and the reduction rate of arable land was greatly increased, and the main types of conversion were forest and grass. At the same time, the area of forest and grass has also greatly increased due to the beginning of the project of returning farmland to the forest. According to Table 5, the main transfer type is also arable land. At the same time, in the early 21 st century, China's society developed rapidly, the urbanization 
process accelerated, and the main type of transfer was arable land.

Table 5 Transfer matrix of land use types in the study area from 2000 to $2005(\mathrm{~km} 2)$

\begin{tabular}{|c|c|c|c|c|c|c|}
\hline \multirow[b]{2}{*}{2000} & \multicolumn{6}{|c|}{2005} \\
\hline & Grass & $\begin{array}{l}\text { Town and } \\
\text { country }\end{array}$ & Arable land & Forest & Water area & Unused area \\
\hline Grass & $\begin{array}{c}45097.3984 \\
2\end{array}$ & 20.897168 & 300.612855 & 468.292252 & 18.546955 & 45.762937 \\
\hline $\begin{array}{l}\text { Town and } \\
\text { country }\end{array}$ & 2.780769 & $\begin{array}{c}2199.2888 \\
21\end{array}$ & 23.089699 & 0.421173 & 1.038354 & 0.030777 \\
\hline Arable land & 814.322533 & $\begin{array}{c}229.18337 \\
2\end{array}$ & 52447.5511 & 610.294628 & 90.507136 & 4.855583 \\
\hline Forest & 46.1498 & 16.170546 & 19.39619 & $\begin{array}{c}20421.3068 \\
2\end{array}$ & 4.120245 & 12.26055 \\
\hline Water area & 3.092748 & 4.482719 & 41.735879 & 1.072158 & $\begin{array}{c}1364.9623 \\
38\end{array}$ & \\
\hline Unused area & 57.078922 & 4.030781 & 25.908805 & 9.342373 & 3 & 4767.258816 \\
\hline
\end{tabular}

During the period 2000-2005, the SPI value first increased, and then began to decrease after reaching a peak in 2003 (Figure 5). Forest had the smallest SPI value in 2000 at -0.50254. The SPI value of town and country is the largest at -0.41615 . In 2005, the SPI value of forest land is still the smallest at -0.56044 . The SPI value of arable land is the largest, which is 0.46885. During this period, the land use type in Dingbian changed, and there was a change from arable land to town and country. The change of land use type has a greater impact on SPI, which is $-0.01343 \mathrm{yr}-1$. For other sites with the same land use type, the rate of change of SPI is smaller than that of Dingbian. The change rate of arable land is the smallest, which is $-0.0035 \mathrm{yr}-$ 1. The forest land had the largest rate of change, $-0.01137 \mathrm{yr}-1$. From this stage, the response relationship of the drought index to land use has changed. The drought intensity of forest is still the largest, but the drought intensity of town and country is greater than that of arable land. The response relationship of forest to drought became the largest, followed by town and country, and finally arable land. The reason may be that the disturbance intensity of arable land has been greatly increased by human activities.

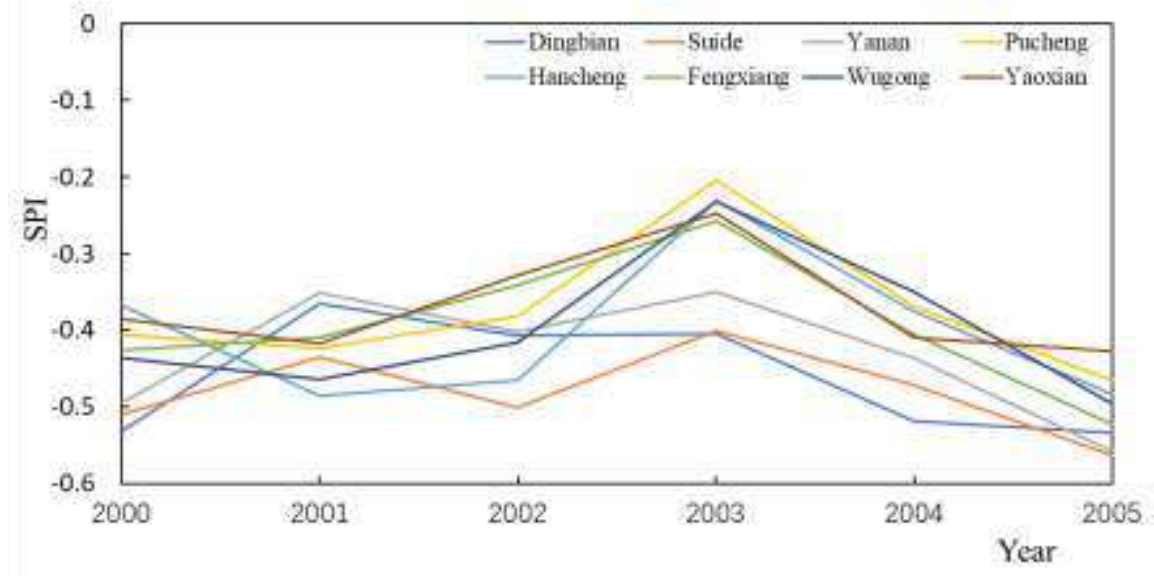




\subsection{From 2005 to 2010}

Figure 5 SPI changes at each site from 2000 to 2005

From 2005 to 2010, according to Table 6, the area of arable land, water area and unused land decreased by $0.33 \%, 2.29 \%$ and $1.87 \%$ respectively. With the deepening of the transformation of farmland to forest, the area of forest land, grassland and town continued to increase, increasing by $0.98 \%, 0.01 \%$ and $2.73 \%$ respectively. In the most reduced water area, the main type of transfer out is arable land, and the type of transfer out of unused land is grass. The increase of town and country areas still maintains a relatively rapid rate, and the main type of transfer is arable land. Arable land occupies a large proportion in the complex conversion of land use types.

Table 6 Transfer matrix of land use types in the study area from 2005 to $2010(\mathrm{~km} 2)$

\begin{tabular}{|c|c|c|c|c|c|c|}
\hline \multirow[b]{2}{*}{2005} & \multicolumn{6}{|c|}{2010} \\
\hline & Grass & $\begin{array}{c}\text { Town and } \\
\text { country }\end{array}$ & Arable land & Forest & Water area & Unused area \\
\hline Grass & $\begin{array}{c}45794.2664 \\
1\end{array}$ & 9.700376 & 83.512163 & 112.528167 & 7.728545 & 9.087991 \\
\hline $\begin{array}{l}\text { Town and } \\
\text { country }\end{array}$ & 0.18628 & $\begin{array}{c}2464.2953 \\
59\end{array}$ & 9.492134 & 0.053636 & 0.025998 & \\
\hline Arable land & 115.281667 & 68.294851 & 52515.0542 & 103.44604 & 47.328995 & 7.923942 \\
\hline Forest & 12.509451 & 5.038267 & 10.169067 & $\begin{array}{c}21478.4926 \\
5\end{array}$ & 1 & 0.056775 \\
\hline Water area & 14.867528 & 1.030777 & 63.374712 & 5.746214 & $\begin{array}{c}1388.2928 \\
03\end{array}$ & 1.671161 \\
\hline Unused area & 91.860299 & 3 & 16.253978 & 1.257804 & 0.824754 & 4715.971828 \\
\hline
\end{tabular}

During the period from 2005 to 2010, the change of SPI generally showed a stable trend with little change (Figure 6). Forest land had the smallest SPI value in 2005 at -0.56044 . The SPI value of arable land is the largest, which is -0.46885 . In 2010, the SPI value of forest land is still the smallest, which is -0.51991 . The SPI value of arable land is the largest at -0.41049 , followed by town and country, with an SPI value of -0.46269. During this stage, the land use type of Hancheng changed from arable land to town and country. In the case of changes in land use types, compared with other sites with no changes in land use types, Hancheng has a larger change rate of -0.0048 , and is the only site with a decreasing SPI value. The change rate of arable land is the smallest, which is 0.002225 . The forest land had the largest rate of change, 0.00475 . This stage is the same as the previous stage, the drought intensity of forest is still the largest, but the drought intensity of town and country is greater than that of arable land. Forest had the greatest response to drought, followed by town and country, and finally arable land. 


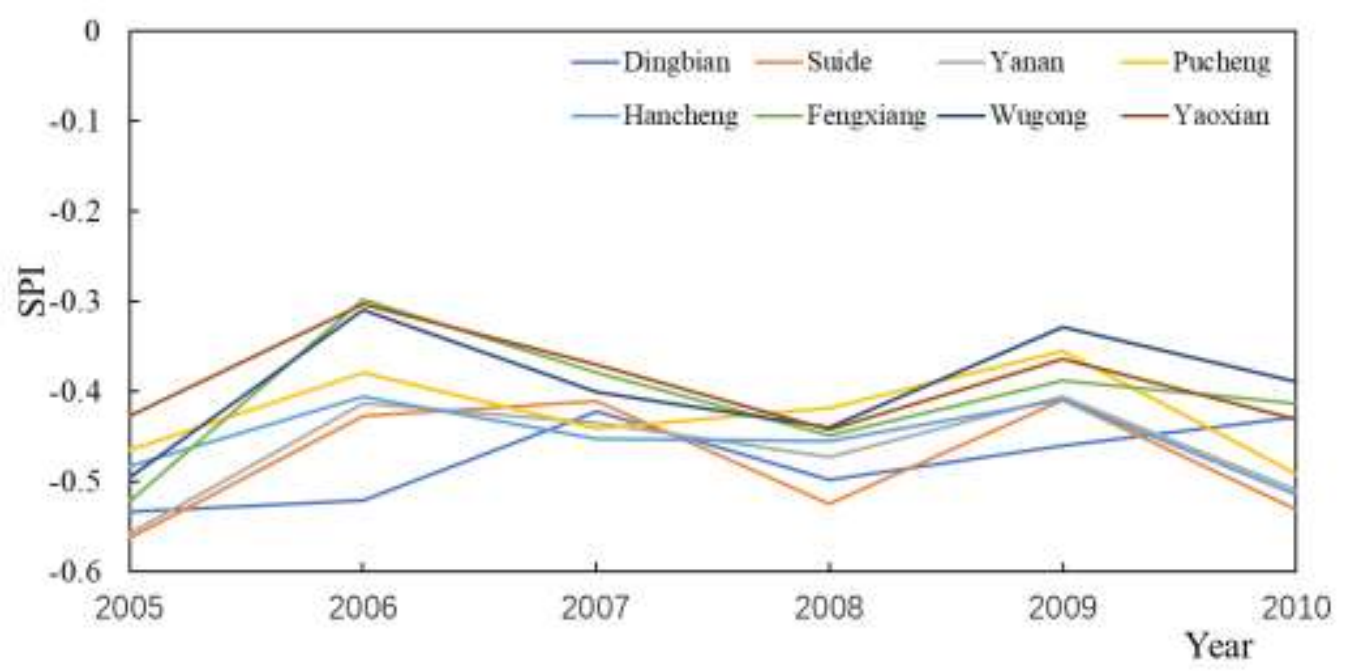

Figure 6 SPI changes at each site from 2005 to 2010

\section{Discussion}

The change of land use type in each stage represents the difference of ecological environment in each stage, and the impact on meteorological drought is also different [27]. From the aspect of different land-use types, the response relationship of drought index SPI to different land-use types is analyzed in this paper. Since the land use types of the stations in this study only involve three types of arable land, forest, and town and country, only the SPI values of these three types are sorted.

According to the above analysis, it can be seen that the outcomes of this study show that the law is divided into two stages which are the 20th century and the 21 st century. From the perspective of drought intensity, from 1980 to 2010, the drought intensity of forest has always been the largest. The vegetation of the forest is less disturbed by humans and is sensitive to climatic conditions. Under the local dry and rainy climate conditions, the drought intensity is relatively large, while the drought intensity of the arable land and town and country are relatively small. However, in the 20th century, the intensity of aridity of arable land was greater than that of town and country. In the 21st century, it was less than that of town and country. This is because with the continuous advancement of farming technology, the disturbance of human activities, such as water-saving irrigation technology, has improved water use efficiency and alleviated the drought of arable land [28].

In the same period, the changing trend of SPI is roughly the same, but the change degree is different, indicating that different land uses have different degrees of adjustment to climate. The drought had the weakest response to the forest in the 20th century and had the least impact on SPI. This is because forest species have deep root systems, and under severe drought conditions, they can use the water stored in the deep soil to alleviate changes in arid climates [29]. However, due to the time lag effect of deep soil moisture changes with precipitation, the response of forest species to drought may be delayed [30]. Therefore, after the 21 st century, with the project of returning farmland to forest moving forward, the forest area has increased substantially, and the impact of forest land on drought has become the largest. During the 20th century, drought had the greatest degree of response to arable land. Crops on arable land are 
restricted by natural conditions such as rainfall and temperature, so they have a strong response to drought. From 2000 to 2010, arable land had the least response to drought. Except for the natural climatic conditions, the possible reason is that the arable area is more affected by irrigation and artificial water diversion, so the SPI cannot fully reflect the degree of surface aridity [31]. After the 21 st century, the drought intensity of town and country is greater than that of arable land, and the degree of influence on the drought index is also greater than that of arable land. This is because with the in-depth development of urbanization, the urban heat island effect increases, and the intensity of drought also increases, which also has influence on the change of drought [32].

Land use is the result of the connective effect of nature and humanity. Climate change affects the growth of vegetation, and the mutual conversion of unused land, grass and forest land occurs. In addition, due to economic development, the type of land use has been transformed from arable land to town and country due to human action [33]. Changes in several different land-use types also have large or small impacts on drought. Both arable land and town and country are disturbed by human activities, but the greening construction inside the city has been improved [34]. The rate of change in the same period is compared. Therefore it can be seen that the transition from arable land to grass and the change from arable land to town and country have a greater impact on drought, while the transition from town to grass and grass to town has less impact on drought.

In summary, types of land use mainly affect the response relationship of drought to them through the degree of vegetation coverage and the disturbance of human activities. Therefore, while monitoring the local drought, we should not only attach importance to the local climate change, but also attach importance to the impact of human activities. In this study, different types of land use may cancel each other out and then affect the average value of the drought index. For example, arable land is converted into the grass, and some grasslands are reclaimed into arable land. The impact of land-use change on drought index needs to be further studied in depth and detail.

\section{Conclusion}

1. From 1980 to 2000 , the drought intensity of various land-use types was: forest $>$ arable land $>$ town and country. From 2000 to 2010, the drought intensity of various land-use types was: forest $>$ town and country $>$ arable land.

2. The response degree of drought index to land use types is different. From 1980 to 2000, arable land had the greatest response to drought index, followed by town and country, and forest had the weakest response to drought index. In the 21 st century, the forest has the strongest response to drought index, followed by town and country, and finally arable land.

3. The area of forest, grass and town and country is increasing continuously, while the area of arable land is decreasing year by year, and the types of land use are constantly undergoing complex changes. The drought index has a strong response to the change of arable land to grass and arable land to town and country, but has a weak response to the mutual transformation of grass and town and country. 


\section{References}

[1] Zhang Qiang, Yao Yubi, Li Yaohui, Luo Zhexian, Zhang Cunjie, Li Dongliang, Wang Runyuan, Wang Jinsong, Chen Tianyu, Xiao Guoju, Zhang Shuyu, Wang Shigong, Guo Nio, Bai Huzhi, Xie Jinnan, Yang Xingguo, Dong Anxiang, Deng Zhenyong, Ke Xiaoxin, Xu Guochang. Drought in Northwest China Research progress and prospect of meteorological disaster monitoring, early warning and disaster mitigation technology [J]. Advances in Earth Science, 2015, 30(02): 196-213.

[2] $\mathrm{Wu}$ J,Chen $\mathrm{X}$, Yao H,et al.Non-linear relationship of hydrological drought responding to meteorological drought and impact of a large reservoir[J].Journal of Hydrology,2017,551:495-507.

[3] Wang Jinsong, Guo Jiangyong, Zhou Yuewu, et al. Research progress and prospect of drought indicators [J]. Geography of Arid Areas, 2007, 30(1): 60-65.

[4] Qian Zhengan, Song Minhong, Wu Tongwen, Cai Ying. A review of the research trends and progress of world arid climate (II): main research progress [J]. Plateau Meteorology, 2017, 36(06): 1457-1476.

[5] Yang Rui, Geng Guangpo, Zhou Hongkui, Wang Tao. Temporal and spatial evolution characteristics of meteorological drought in Weihe River Basin based on SPEI_PM index [J]. China Agricultural Meteorology, 2021, 42(11): 962-974.

[6] Wang Shuo and Cui Chenfeng and Dai Qin. Contributions of Vegetation Greening and Climate Change to Evapotranspiration Trend after Large-Scale Vegetation Restoration on the Loess Plateau, China[J]. Water, 2021, 13(13) : 1755-1755.

[7] Mahtab Nazarbakhsh and Andrew M. Ireson and Alan G. Barr. Controls on evapotranspiration from jack pine forests in the Boreal Plains Ecozone[J]. Hydrological Processes, 2020, 34(4) : 927-940.

[8] Konapala G,Mishra A.Review of complex networks application in hydroclimatic extremes with an implementation to characterize spatio-temporal drought propagation in continental USA[J].Journal of Hydrology,2017,555:600-620.

[9] Apurv T,Sivapalan M,Cai X M.Understanding the role of climate characteristics in drought propagation[J].Water Resources Research,2017,53:9304-9329.

[10]Apurv T,Sivapalan M,Cai X M.Understanding the role of climate characteristics in drought propagation[J].Water Resources Research,2017,53:9304-9329.

[11] Jehanzaib M,Kim T W.Exploring the influence of climate change-induced drought propagation on wetlands[J]. Ecological Engineering, 2020, 149:105799. doi:10.1016/j.ecoleng. 2020. 105799.

[12] Wu J F,Chen X W,Love C A,et al.Determination of water required to recover from hydrological drought:Perspective from drought propagation and non-standardized indices[J].Journal of Hydrology,2020,590:125227.doi:10.1016/j.jhydrol.2020.125227.

[13] Jehanzaib M,Sattar M N,Lee J H,et al.Investigating effect of climate change on drought propagation from meteorological to hydrological drought using multi- 
model ensemble projections[J].Stochastic Environmental Research and Risk Assessment,2020,34:7-21.

[14]Zhou J J,Li Q Q,Wang L Y,et al.Impact of climate change and land-use on the propagation from meteorological drought to hydrological drought in the eastern Qilian Mountains[J].Water,2019,11:1602.doi:10.3390/w11081602.

[15] Xu Y,Zhang X,Wang X,et al.Propagation from meteorological drought to hydrological drought under the impact of human activities:A case study in northern China[J].Journal of Hydrology,2019,579:124147.doi:10.1016/j.jhydrol.2019.124147.

[16]Kong Gang, Zhang Shanliang, Wang Lu, Huang Shengzhi, Bai Jueying.Analysis on the spatiotemporal evolution of drought characteristics of different grades in Yulin City[J].People's Pearl River,2021,v.42;No.283(11):29-37.

[17] Wang Jiarui, Sun Congjian, Zheng Zhenjing, Li Xiaoming.Characteristics of drought on the Loess Plateau and its relationship with atmospheric circulation in the past 57 years[J].Acta Ecology,2021,41(13):5340-5351.

[18]Liu Lili, Han Lei, Han Yonggui, Gao Yang, Peng Ling. Temporal and spatial variation of aridity index in Northwest China from 1989 to 2019 and its response to climatic factors [J]. Chinese Journal of Applied Ecology, 2021, 32(11): 4050-4058 .DOI: 10.13287/j.1001-9332.202111.014.

[19]McKEE T B, DOESKEN N J, KLEIST J. The relationship of drought frequency and duration of time scales [C] // Eighth Conference on Applied Climatology. American Meteorological Society, 1993: 179-186.

[20]Chen Lili, Liu Puxing, Yao Yulong, Zhu Xiaojuan, Zhao Minli. Annual and Spring Variation Characteristics of SPI and Z Index in Different Climate Regions of Gansu Province from 1960 to 2010 [J]. Journal of Ecology, 2013,32(03):704-711. DOI : 10. 13292/j. 1000-4890. 2013. 0095.

[21] Sun Zhihui, Wang Zhiliang, Cao Xuemei, Yang Qiong, Liu Zhichao, Lei Yanpeng. Variation characteristics of drought in Shaanxi Loess Plateau from 1971 to 2010 based on standardized precipitation index[J]. China Desert, 2013,33(05):1560-1567.

[22]Liu Canran, Chen Hao, Ning Chen, Ding Yongjian.Analysis of drought characteristics in Shaanxi Province from 1961 to 2016 based on SPI[J].Jiangxi Agricultural Journal,2018,30(04):117-122.

[23] Wang Xiaofeng, Hu Chunyan, Wei Wei, Yu Yang. Temporal and spatial characteristics of drought in the Loess Plateau of Weibei based on SPI[J].Journal of Ecological Environment,2016,25(03):415-421.

[24] Wang Zhiwei, Yang Shengtian, Sun Ying, Dong Baoen, Zhao Changsen, Zhao Haigen, Zhou Xu, Lou Hezhen, Liu Xiaolin. Effects of climate and land use changes on the variation of drought index in Wuding River Basin from 1982 to 2010 [J]. Hydrology (Phase 3) :17-23.

[25](QUAN Bin. The Introduction to Land Use and Land Cover Change [M]. Beijing: China Science and Technology Press, 2010.

[26]CHENG Lei, XU Zongxue, LUO Rui, et al. Spatial -temporal characteristics of lucc 
and driving factor analysis for the Wei River basin from 1980 to 2000 [J]. Research of Soil and Water Conservation, 2009,16(5):1-6+30.

[27]Li Yanju, Ding Jianli, Zhang Junyong, et al. Response of vegetation cover to drought on the northern slope of Tianshan Mountains from 2001 to 2015: Based on land use/land cover analysis [J]. Chinese Journal of Ecology, 2019.

[28]Davidson E A, Verchot L V, Catt · nio J H, Ackerman I L, Carvalho J E

M. Effects of soil water content on soil respiration in forests and cattle pastures of eastern Amazonia. Biogeochemistry, 2000, 48( 1) : 53-69.

[29]Anderegg W R L, Schwalm C, Biondi F, Camarero J J, Koch G, Litvak M, Ogle K, Shaw J D, Shevliakova E, Williams A P, Wolf A, Ziaco E, Pacala S. Pervasive drought legacies in forest ecosystems and their implications for carbon cycle models. Science, 2015, 349(6247) : 528-532.

[30]Deng X P, Shan L, Zhang H P, Turner N C. Improving agricultural water use efficiency in arid and semiarid areas of China. Agricultural Water Management, 2006, 80(1/3):23-40.

[31]Jiang Wenjun, Zhao Hongmei, Tang Hao. Research on the relationship between surface drought and urban surface heat island in the Poyang Lake area [J]. Journal of Central China Normal University (Natural Science Edition), 2017,51(04):555560.DOI:10.19603/ j.cnki.1000-1190.2017.04.022.

[32] Yang J, Huang C H, Zhang Z Y, Wang L. The temporal trend of urban green coverage in major Chinese cities between 1990 and 2010. Urban Forestry \& Urban Greening, 2014, 13(1) : 19-27. 